NBER WORKING PAPER SERIES

\title{
WAGE FLEXIBILITY AND EMPLOYMENT FLUCTUATIONS: EVIDENCE FROM THE HOUSING SECTOR
}

\author{
Jörn-Steffen Pischke \\ Working Paper 22496 \\ http://www.nber.org/papers/w22496 \\ NATIONAL BUREAU OF ECONOMIC RESEARCH \\ 1050 Massachusetts Avenue \\ Cambridge, MA 02138 \\ August 2016
}

I thank Alexander Lembke, Georg Graetz, and Felix Koenig for excellent research assistance, and Alan Manning, Guy Michaels, Albert Saiz, and Orie Shelef for helpful comments. This research has been supported by a grant from the ESRC to the Centre for Economic Performance at the LSE. The views expressed herein are those of the author and do not necessarily reflect the views of the National Bureau of Economic Research.

NBER working papers are circulated for discussion and comment purposes. They have not been peer-reviewed or been subject to the review by the NBER Board of Directors that accompanies official NBER publications.

(C) 2016 by Jörn-Steffen Pischke. All rights reserved. Short sections of text, not to exceed two paragraphs, may be quoted without explicit permission provided that full credit, including () notice, is given to the source. 
Wage Flexibility and Employment Fluctuations: Evidence from the Housing Sector Jörn-Steffen Pischke NBER Working Paper No. 22496

August 2016

JEL No. E24,J20,J44

\begin{abstract}
$\underline{\text { ABSTRACT }}$
Many economists suspect that downward nominal wage rigidities in ongoing labor contracts are an important source of employment fluctuations over the business cycle but there is little direct empirical evidence on this conjecture. This paper compares three occupations in the housing sector with very different wage setting institutions, real estate agents, architects, and construction workers. I study the wage and employment responses of these occupations to the housing cycle, a proxy for labor demand shocks to the industry. The employment of real estate agents, whose pay is far more flexible than the other occupations, indeed reacts less to the cycle than employment in the other occupations. However, unless labor demand elasticities are large, the estimates do not suggest that the level of wage flexibility enjoyed by real estate agents would buffer employment fluctuations in response to demand shocks by more than 10 to 20 percent compared to completely rigid wages.
\end{abstract}

Jörn-Steffen Pischke

CEP

London School of Economics

Houghton Street

London WC2A 2AE

UNITED KINGDOM

and NBER

s.pischke@1se.ac.uk 


\section{$1 \quad$ Introduction}

In the traditional Keynesian model, unemployment occurs during recessions because nominal wages are downwardly rigid. Firms lay off works rather than lowering their wages in recessions. Such explanations for employment fluctuations over the business cycles retain their appeal in modern discussions (e.g. Bewley, 2002). While downward wage rigidity is well documented (see below), there is much less evidence linking wage rigidity directly to employment fluctuations or unemployment. This paper intends to contribute to this debate by comparing the employment response of three different housing market related occupations, real estate agents, architects, and construction workers, to the housing market cycle.

The focus on three such narrow occupations is interesting because pay arrangements differ substantially across these occupations. Real estate agents receive most or all of their pay in the form of commissions. As a result, the "wage" implicit in their employment arrangement is in essence fully flexible. If the housing market turns down and prices fall or transactions dry up, the earnings of real estate agents drop commensurately. There is no a priori reason for brokerages (the employers of agents) to lay off agents; the same number of agents could stay in their job at the new lower wage. Of course, agents may decide to quit when employment is becoming less attractive as these workers move along their labor supply curve. Architects and construction workers, on the other hand, are largely paid on standard wage and salary contracts, although overtime pay and bonuses, which provide some degree of flexibility, are common in these occupations. As these occupations should also be affected by the housing cycle, they serve as a useful control group for the real estate agents.

Apart from the different contractual arrangements, another attraction for studying the housing market are the large booms and busts, which have taken place in the market over the past 15 years. Moreover, there are large differences in the amplitude of housing market cycles across different parts of the United States. Figure 1 shows house prices in California, Indiana, and New York. States on both coasts saw large run ups in prices during the 2000s while price increases were modest in in the Midwest. The figure also shows that the bust in the housing market after 2006 was much more pronounced in California than in New York. 
In this paper, I am exploiting this variation in fluctuations in house prices and transactions across states and time in the 2000s. I utilize these fluctuations as a proxy for labor demand shocks for the occupations under study. For real estate agents the connection is a very direct one: their commission is a percentage of the transactions value so that the product of prices and transactions directly affects their earnings. For architects and construction workers the connection is more indirect but new housing starts tend to be closely related to the housing cycle.

I interpret fluctuations in the housing market as shocks to the labor demand for the occupations I study. The compensation of both real estate agents and architects is small compared to the total value of houses or housing transactions so that shocks originating from the labor markets for these workers are unlikely to play any significant role in overall movements of the housing market. For construction workers this may be more problematic as the costs of construction are a larger portion of new housing costs. Nevertheless, the perception of most observers is that housing market fluctuations primarily stem from demand side pressures. For example, Glaeser, Gyourko and Saks (2005) and Glaeser, Gyourko and Saiz (2008) explain the divergent housing cycles across US cities by an interaction of increasing housing demand and land use regulations. Gyourko and Saiz (2006) find that construction costs did not contribute to the recent observed housing price cycles.

Combining data from the American Community Survey (ACS) and the Quarterly of Workforce Indicators (QWI) with real estate prices and transactions mostly for the first decade in the 2000s, I estimate the response of wages and employment in each of the occupations with respect to the value of transactions in the housing market. Since the scaling of these responses will naturally differ depending on how directly the occupation is affected by these market fluctuations, my preferred measure is to divide the employment response by the wage response to obtain an elasticity which can be thought of as the labor supply or inverse wage setting elasticity for the occupation. The estimated elasticities are around 2 to 3 for real estate agents, 3 to 4 for architects, and large but variable for construction workers. These results are consistent with the idea that the wage setting curve for real estate agents is the most upward sloping while it is much more elastic for the other occupations. These estimates are effectively IV estimates of employment on wages instrumenting with housing market fluctuations. These estimated elasticities line up according to the flexibility with which wages are set in the different 
occupations. However, the elasticities for architects and construction workers are estimated imprecisely because their wage responses are very modest. While the pattern is right, a simple back-of-the-envelope calculation suggests that the differences are not large enough to explain much of the employment fluctuations over business cycle.

This paper relates to a large literature documenting pervasive downward nominal wage rigidity. Prominent examples are Card and Hyslop (1997), Kahn (1997), and Altonji and Devereux (2000) for the US and Dickens et al. (2007), who report results from a consortium assessing wage rigidity in 16 countries. ${ }^{1}$ While these papers are motivated by the importance of wage rigidity for employment fluctuations they focus on documenting the relative absence of negative nominal wage changes and how these relate to inflation. On the other hand, this literature does not relate wage rigidity directly to employment fluctuations or labor demand shocks.

An exception is the paper by Fehr and Goette (2005) for Switzerland, who correlate estimates of wage rigidity across different inflation regimes and cantons to unemployment rates. They find that unemployment is higher when there is more "wage sweep up" due to nominal wage rigidity. Inflation creates implicit variation in the bite of nominal wage rigidity but does not directly distinguish more or less flexible contracting arrangements. Hence, their paper does not address directly whether more flexible wage contracts would lead to less unemployment.

Card (1990) relates employment fluctuations directly to contracts with more or less flexibility. He exploits the wage indexing provisions of Canadian union contracts to estimate the employment response to unexpected price changes. Union contracts which do not specify any indexing to future price changes fix nominal wages in either direction. Unexpected inflation then resets the wage. Card (1990) interprets the resulting employment fluctuations as movements along a labor demand curve. This differs somewhat from the exercise I am interested in here, which is focused on the response of employment to labor demand shocks

\footnotetext{
${ }^{1}$ Despite this evidence, there is considerable debate about the importance of nominal wage rigidity. For example, the absence of wage cuts may be due to measurement error in survey data. Elsby, Shin, and Solon (2016) show that wage cuts are much more frequent in administrative data (which have their own problems) than in survey data, and conclude that wages of many job stayers were reasonably flexible during the Great Recession.
} 
under different wage contracting regimes. Instead of a labor demand curve I am trying to estimate the wage setting schedule under different contracting regimes.

Holzer and Montgomery (1993) are interested in the response of wages and employment to firm level demand shocks. Using firm level data, they proxy demand shocks by sales growth. However, in a broad cross-section of firms, sales might reflect both demand and supply conditions. Kaur (2014) studies agricultural labor markets in India, which allows her to construct a more credible measure of demand shocks due to rainfall. However, her market is one for day laborers. As a result, there is no context of a "layoff" in her setting. Rather, she shows that an increase in the spot market wage due to favorable conditions in one year persists into the subsequent year when the reasons for the higher wage have dissipated, and this translates into lower employment. This notion of rigid wages is more closely associated with rigidity in starting wages rather than the wages in ongoing employment contracts. But wages in new jobs are believed to be relatively responsive to labor market conditions in the US, see for example Beaudry and DiNardo (1991), Baker, Gibbs, and Holmstrom (1994), and Pissarides (2009).

Most closely related to my investigation is a paper by Lemieux, MacLeod, and Parent (2012). They separate workers into those who work on standard fixed wage contracts and those whose who receive part of their compensation as bonus pay. Regressing wages, hours and earnings on a bonus pay dummy interacted with the unemployment rate (as a cyclical indicator) they find larger cyclical effects on wages in bonus jobs and larger effects on hours in fixed wage jobs. However, bonus pay is a relatively minor component of total compensation in many jobs, and my paper uses occupations with bigger differences in pay setting regimes. Housing market fluctuations are also likely a better labor demand indicator than the unemployment rate.

Also related is the study by Card, Kramarz, and Lemieux (1999) who correlate relative employment changes to changes in the cross-sectional wage distribution over time in a particular country. This more aggregate investigation ranks three countries, the US, Canada, and France, by the relative rigidity of their wage setting institutions. This is close in spirit to the informal ranking of three different occupations in my study.

An important prior analysis focusing on real estate agents is the closely related exercise by Hsieh and Moretti (2003). They also regress changes in RE agent employment and earnings on 
changes in house prices. They find an elasticity close to 1 for employment and almost no response of earnings. However, in contrast to my investigation they look at relatively long run (10 year) changes during a period when the housing market in the US was mostly booming. They interpret their results as inefficient entry of workers into an industry where the commission rates on sales tend to be fixed irrespective of house price levels. A relative elastic supply of RE agents absorbs any potential wage gains as the proceeds are being spread across more workers. My study focuses on year-to-year changes which are more likely to capture business cycle fluctuations. In particular, my sample period includes the sharp downturn in many housing markets after 2006, which is relevant for the wage flexibility story. Unlike my study, Hsieh and Moretti don’t compare wages and employment to any other housing related occupations.

\section{Institutional Arrangements and Analytical Framework}

Real estate agents and brokers facilitate transactions between buyers and sellers in the housing market. An individual has to obtain a state license after completing some coursework in order to act as a real estate agent; the entry requirements for this occupation are not large. After some experience and/or with additional education, individuals can qualify as a broker, which allows them to set up their own brokerage. ${ }^{2}$ A broker typically employs various agents, who will execute the sales of individual properties. In most states and transactions, a seller enters a legal relationship with a brokerage. The designated agent will carry out a number of specified services related to the transaction for the client. These services include finding a buyer but typically also involve various legal obligations associated with the sale. Clients pay a fee in the form of a commission on the sales price to the brokerage for these services.

Agents are employed by brokers on a variety of contracts. The most common ones involve agents receiving a share of the commission revenue for their sales; this is often referred to as percentage commission splits. Shares of 50 to 80 percent are common in the industry. Very few agents receive a fixed base salary or are paid solely on a salaried basis. However, it is not uncommon for an agent to actually pay the broker a monthly fee while receiving a large share of

\footnotetext{
${ }^{2}$ The specific regulations and nomenclature differs across states.
} 
their commission revenue, often 100 percent in this case. In industry parlance these agents "pay for their desk.” In addition to desk fees these agents typically cover their own business expenses (NAR RealtorMag, 2014a; NAR 2014; Shelef and Nguyen-Chyung, 2015).

There is little precise information on flexible components of pay like commissions. Various labor market surveys contain some coarse information, typically combining sources such as bonuses, commissions, and overtime. The top panel in Table 1 displays the share of workers receiving pay from overtime, tips, and commissions from the CPS for the three occupations analyzed here. ${ }^{3}$ Potentially, all these pay components are related to performance and the amount of work available. More than half the real estate agents respond to receive such flexible pay compared to $10-15$ percent of architects and construction workers. For construction workers this is presumably mostly overtime, which will lose its relevance once hours fall below the threshold for overtime pay. As a result, overtime pay provides some wage flexibility in a downturn but wages eventually turn rigid.

I augment the CPS results with information from industry sources. According to the Member Profile of the National Association of Realtors, 95 percent for agents and brokers receive some flexible pay component, which in most cases will be commissions. It is unclear why the CPS fraction is much lower. NAR members are more likely brokers or more experienced and higher earning agents. These groups tend to be on more high powered contracts but these agents are also more likely to receive a salary. However, if anything, this suggests that the fraction reporting commissions in the more representative CPS should be even higher.

The second panel in Table 1 collates information on the share of pay that is due to the flexible pay components. Unfortunately, I have only been able to locate such information from industry sources for architects and construction workers, for whom only 5 percent is due to such pay components. The last number for construction workers on fringe costs of 19 percent is probably an overstatement for my purposes, as a large proportion of fringe costs is likely part of fixed pay, like employer contributions to health insurance premia. Unfortunately, detailed information is not available for real estate agents but the numbers are likely to be substantially higher as

\footnotetext{
${ }^{3}$ The CPS asks “(Do / Does) (name/you) usually receive overtime pay, tips, or commissions at (your/his/her) MAIN job?”
} 
commission shares below 50 percent are rare. NAR (2014) reports that 13 percent of agents are on 100 percent commissions and 73 percent on percentage commission splits.

One issue is whether we should think of agents as actually employed by brokers at all, or as effectively self-employed. The IRS has rules as to when agents should be classified as independent contractors or employees. States have their own rules, often based on common law guidelines, to determine whether agents are covered by unemployment insurance and workers compensation (NAR RealtorMag, 2014b). For example, NAR (2014, exhibit 4-4) reports that 83 percent of their members are independent contractors and hence effectively self-employed. However, it is important to keep in mind that almost half of the responses come from brokers rather than agents.

On the other hand, 49 percent of real estate agents self-identify as employed in the sample from the American Community Survey I use below. This compares to 72 percent of architects and 75 percent of construction workers. In practice, many real estate agents seem to think of themselves as employees.

The contracts of real estate agents closely approximate a simple, optimal agency contract we are used to seeing in a textbook. Such a contract involves a negative intercept and a slope of 1 . Figure 2 illustrates how agent earnings are a function of the total value of transactions. These values are the product of the average sales price of a property in market $m\left(P_{m}\right)$ and the number of transactions (sales) agent $i$ completes in a month $\left(S_{i m}\right)$. Agent earnings are

$$
Y_{i m}=\gamma+\delta c P_{m} S_{i m}
$$

where $\gamma$ is the base salary or desk fee, $\delta$ is the share of the commission the agent receives (say 0.5), and c is the commission rate (e.g. 0.06) on the transactions value. I use $\ln \left(P_{m} S_{m}\right)$ as my measure of labor demand shocks in the empirical analysis below, where $S_{m}$ are market level sales. As Figure 2 illustrates, agent earnings and wages fluctuate directly with transactions values in the housing market.

Note that market level transactions $S_{m}=\Sigma_{i} L_{m} S_{i m}$, where $L_{m}$ is the number of real estate agents working in market $m$. Fluctuations in the housing market will directly affect $P_{m}$ and $S_{m}$. Hsieh 
and Moretti (2003) have shown that the number of active real estate agents $L_{m}$ responds strongly to price booms, at least at a decadal horizon. Hence, $S_{m}$ tends to rise when prices rise but $S_{i m}$ could well fall if $L_{m}$ expands enough. Every agent simply sells fewer houses in a boom so that agent earnings stay the same. In fact, Hsieh and Moretti (2003) find that average earnings of agents don't rise in booming markets. I am using the market level $\ln \left(P_{m} S_{m}\right)$ as my cyclical indicator and I want this to affect agent earnings. However, unlike Hsieh and Moretti I am looking at annual data and I will show below that agent earnings are responsive to $\ln \left(P_{m} S_{m}\right)$ at that frequency.

The analysis in this paper is based on a simple demand and supply framework analogous to Card, Kramarz, and Lemieux (1999), where the wage setting institutions differ across occupational labor markets. Figure 3 illustrates this for two occupations, say real estate agents and construction workers. Each occupation has a wage setting (or labor supply) curve and a labor demand curve. The wage setting curve for construction workers is inelastic, reflecting the relatively rigid wages for this group of workers. The wage setting curve for real estate agents is elastic as the wages for this group adjust flexibly to changes in the labor market. Figure 3 shows a common labor demand curve for each of the two groups. When labor demand shifts inwards, as during the housing bust from 2006 - 09, wages fall little for construction workers, while there is a large adjustment in employment. The opposite happens for real estate agents where wages fall more and employment adjusts less.

I treat the market indicator $\ln \left(P_{m} S_{m}\right)$ as a labor demand shifter, and interpret the ratio of the employment to the wage response to shocks as the inverse wage setting elasticity of the occupation. The value of housing transactions should measure the labor demand for real estate agents very well, as it is directly related to their commissions based earnings. The link for the other occupations is more indirect. Architects and construction workers are primarily engaged in new construction of housing. New housing permits correlate closely with the transactions measure: the elasticity from a panel regression of permits on the transactions value controlling for state and time effects is a highly significant 0.37 . Hence, transactions values should be an appropriate measure for the labor demand of architects and construction workers as well but the wage and employment effects will likely be smaller. 
Another issue with using $\ln \left(P_{m} S_{m}\right)$ as a labor demand shifter for the first decade in 2000s is that the boom and bust cycles in the housing market correlate strongly with the financial crisis and the general downturn of the economy. Since labor demand and supply in Figure 3 are those to an occupation, supply depends crucially on job prospects for workers outside the occupation. An inward shift in labor demand due to the housing bust during the 2006 - 2009 period may therefore coincide with an inward shift of labor supply (or wage setting) because job prospects also deteriorated in other occupations at the same time.

I deal with this in two ways. All regression models are estimated at the state level and control for aggregate time effects. I.e. I only use the within state variation $\operatorname{in} \ln \left(P_{m} S_{m}\right)$. To the degree that the recession due to the financial crisis affected all states similarly this will be washed out by the time effects. To address within state correlations of labor demand and supply shifts I also control for an "alternative wage" for the occupations under analysis. This is given as the wage of all workers in the state with similar characteristics as the workers in the occupation under analysis, and described in more detail in the data section below. It is not a perfect solution as this alternative wage is clearly an equilibrium object.

\section{$3 \quad$ Data}

The analysis combines labor market data for real estate agents, construction workers and architects with data on the economic cycle in the housing sector. Data on the labor market comes from the American Communities Survey (ACS) and from the Quarterly Workforce Indicators (QWI), housing sales transaction data is from the National Associations of Realtors (NAR) and sales prices from the Federal Housing Finance Agency (FHFA).

The ACS is a large-scale annual survey of the US population starting in 2000. I select real estate agents (1990 occupation code 254), architects (43), and construction workers ([occupation codes 563 - 599 or $844-873$ ] and industry code 23) and construct annual employment, average hourly wages, weeks worked per year, and usual hours worked per week for these occupations. The 
hourly wage measure divides wage and salary income by annual hours worked. ${ }^{4}$ Since the aim of this paper is to analyze the effect of rigidity in contracted wages, I exclude the self-employed in the analysis. The main analysis uses data aggregated at the state and year level. While metropolitan areas might be preferable, longer time series of house prices are available at the state level.

To control for potential shifts in labor supply that coincide with demand shifts I construct a measure of workers' “alternative wage.” This variable is meant to proxy for the outside option of workers. It is constructed as a weighted average of the wage of similar individuals working outside a given occupation. The weights are derived from a probit regression of working in that occupation on demographics. To illustrate the process consider the "alternative wage” of a real estate agent. I first estimate a probit model for working as a real estate agent on seven education dummies, race, a squared term in age, and an interaction of gender and marriage dummies. I calculate this probability separately for each sample year. Next I calculate the weighted average wage of all non-real estate agents using the predicted probability of being a real estate agent as weight. This procedure creates an average wage for workers in other occupations who look most similar to real estate agents in terms of observables.

One drawback of the ACS is that samples for specific occupations at the state-year level can be small, leading for imprecise cell averages. I therefore complement the ACS data with data from the QWI, which is mainly based on administrative records of the state unemployment insurance (UI) systems. ${ }^{5}$ While the QWI covers almost the universe of employment contracts in the US, its main drawback is that it excludes jobs outside of the UI system. This excludes the selfemployment and potentially many real estate agents because the commission-based contract prevalent in the industry are exempted from UI coverage in a number of states. Apart from this under-coverage, the QWI will most likely capture the agents with the least flexible contracts.

\footnotetext{
${ }^{4}$ Annual hours multiply weekly hours by weeks worked using mid-points of the reported bins.

${ }^{5}$ The source data for the QWI is the Longitudinal Employer-Household Dynamics (LEHD) linked employeremployee microdata. The LEHD data is a massive longitudinal database covering over 95 percent of U.S. private sector jobs
} 
A second drawback is that the QWI only contains information by industry and not occupation of the workers. Therefore, I use the NAICS industry codes 5312 for Offices of Real Estate Agents and Brokers, 5413 for Architectural, Engineering, and Related Services, and 2361 for Residential Building Construction. This introduces some measurement error as I also capture wages and employment of other occupations like secretaries who are likely on different contracts. The QWI data start at different points in time for different states mostly in the 1990s and early 2000s. This leads to an unbalanced panel but allows me to extend the time period for some states (see the appendix for details on the coverage of the QWI data by state).

The labor market data is linked to data on the regional housing cycle. The data for the total value of housing transactions comes from two sources. The price data is taken from the annual series of house prices by the FHFA (formerly OFHEO). This data is based on mortgages bought by Freddie Mac and Fannie Mae. ${ }^{6}$ The index is calculated using two mortgages on the same property and aggregating the data using the Case and Shiller (1989) method. The data used here uses single-family residential properties only, starts in 1991, and is published annually. Housing sales transactions are obtained from NAR for the years 1989 to 2010. This data is based on reports of local membership groups and again covers existing single-family homes. ${ }^{7}$ Combining the labor market and housing data leads to a panel spanning the years of 2000 to 2010 when using the ACS and an unbalanced panel for the years 1991 to 2010 when using the QWI.

The data on fluctuations in the housing market should capture swings in the demand for the three occupations. My preferred measure is the annual value of house sales given by the product of the number of transactions and the average sales price. For real estate agents, this variable directly tracks the transactions values on which commissions are based. For the other two occupations,

\footnotetext{
${ }^{6}$ The FHFA price index uses mortgage data from the Federal Home Loan Mortgage Corporation (Freddie Mac) and the Federal National Mortgage Association (Fannie Mae). Using an adapted version of the weighted-repeat sales method (Case and Shiller, 1989), the price index is estimated using repeated observations of housing values for individual single-family residential properties on which at least two mortgages were originated and subsequently purchased by either Freddie Mac or Fannie Mae. Source: http://www.fhfa.gov/DataTools/Downloads/Pages/HousePrice-Index-Datasets.aspx\#qpo

${ }^{7}$ The NAR series "Single-Family Existing-Home Sales" is based on closed home sales and captures about 30-40 percent of all home sales in the US. The data is collected from local realtor associations and multiple listing services. This data is not available after 2010. Data is missing in New Hampshire in four years and Idaho in one year. The data were obtained through personal communication with T. Doyle at NAR on Aug 4, 2014.
} 
demand might be thought to be more closely related to the number of new construction projects. To address this point I collected data on the value of new housing permits issued in each year and state from the Census Bureau’s “Building Permits Survey.” A regression of the ln of construction permits on ln housing prices and ln transactions separately yields an $\mathrm{R}^{2}$ of 0.3 within states and years, and 0.2 when the regression is run on the product of prices and transactions. The value of housing sales should therefore also capture demand shifts in architecture and construction well.

\section{$4 \quad$ Empirical Results}

Table 2 shows regression results from running wage and employment regressions of the form

$$
\ln \left(Y_{s t}\right)=\alpha+\beta_{\mathrm{p}} \ln \left(P_{s t}\right)+\beta_{\mathrm{S}} \ln \left(S_{s t}\right)+\phi_{s}+\lambda_{t}+e_{s t}
$$

where $Y_{s t}$ is the wage or employment outcome for realtors in state $s$ and year $t, P_{s t}$ is the housing price index, $S_{s t}$ is the number of home sales, and $\phi_{s}$ and $\lambda_{t}$ are state and year fixed effects,

respectively. Regressions are weighted by the number of individuals in a state. Column (1) shows that a 10 percent increase in prices or sales translates into about 1.5 percent higher hourly wages for real estate agents. Even though the wage elasticity is well below 1, this seems like a substantial effect and is statistically significant. We would expect an elasticity of 1 if the contracts for all agents were simply proportional (i.e. $\gamma=0$ in eq. (1) above), agent employment would not react to labor demand shocks, and transactions volumes $P_{s t} S_{\text {st }}$ were completely accurately measured. None of these are likely to hold. Moreover, the regression is based on repeated cross-sections, and entry and exit effects will tend to bias the estimates of $\beta$ down if less productive agents enter in booms. In any case, the estimates are large compared to the zero effect found by Hsieh and Moretti (2003).

Since the coefficients on prices and sales are very similar as expected (although the p-value for equality is only about 0.04 ) it makes sense to restrict them and work with the transactions value $\ln \left(P_{s t} S_{s t}\right)$ as in column (2) instead. Adding the alternative wage for real estate agents in column 
(3) makes little difference to the result. The estimate for the alternative wage is positive as expected but imprecisely estimated.

Columns (4) to (6) repeat the same regressions for the number of realtors employed. Elasticities are around 0.5 to 0.6 , suggesting substantial employment responses of realtors over the cycle. This mirrors the result of Hsieh and Moretti (2003) that realtors respond to the housing cycle through entry and exit, and this will mute some of the wage effects of market fluctuations. To gauge the size of this response we will have to compare realtors to other occupations, as we will do shortly. The result in column (6) shows that the employment result is also relatively insensitve to entering the alternative wage, which is now negative.

Columns (5) to (9) show results for the average number of weeks worked, and columns (10) to (12) for hours worked per week. There seems to be no adjustment at the intensive margin as housing markets fluctuate. If realtor wages are relatively flexible, we might expect a smaller employment response for this group but some adjustment on the intensive margin. One reason for the absence of an hours response might be the presence of desk fees in agent contracts, as illustrated in Figure 2. Since these fees constitute a fixed cost of work, agents may not want to reduce their hours (very much) in response to housing busts but may still react by leaving the occupation or employment entirely. However, many more agents are on percentage commission splits and may not pay any desk fees. It is also surprising that there is not more of a response at the weeks margin.

It is difficult to gauge whether the wage and employment responses of real estate agents to labor demand shocks are large or small by looking at this occupation in isolation. Therefore, I run similar regressions to (2) for architects and construction workers. Workers in these occupations are on much more standard fixed wage contracts with comparatively minor flexible components like overtime or bonuses. One complication in comparing the $\beta$ coefficients for different occupations is that hosue price and sales shocks may affect real estate agents much more directly than the other occupations. To circumvent this problem, I concentrate on the wage setting elasticity, given by the ratio $\beta_{\text {emp }} / \beta_{\text {wage. }}$ This ratio is free from these scaling problems, since scaling should affect wage and employment results proportionally. Notice that the inverse wage setting elasticity can be obtained from the regression of employment on wages 


$$
\ln \left(L_{s t}\right)=\theta_{0}+\theta \ln \left(W_{s t}\right)+\phi_{s}^{1}+\lambda^{1}{ }_{t}+\eta_{s t}
$$

instrumenting the wage by the demand $\operatorname{shock} \ln \left(P_{s t} S_{s t}\right)$.

Table 3 displays the results. Column (1) repeats the estimates of the employment, weekly hours and wage elasticities with respect to $\ln \left(P_{s t} S_{s t}\right)$ for real estate agents; these are the estimates from columns (5), (11), and (2) from Table 2, respectively. The fourth row gives the inverse wage setting elasticity, which is the ratio of these two estimates. This comes out to 3.5 for the real estate agents. Columns (2) and (3) display the estimates for architects and construction workers. Both employment and wage responses are lower for these occupations, as expected. What is of more interest is the ratio in row (4) which comes out to 3.7 for architects and 28 for construction workers. The wage setting elasticity is imprecisely estimated because the wage effect in the denominator of the ratio is small for both these occupations. The reduced form estimate for weekly hours in row (2) is uniformly small for all occupation; indicating little intensive margin response to labor demand shocks for any of the occupations.

Columns (4) to (6) of Table 3 repeat the same estimates with the QWI data. Both the ACS and the QWI data have advantages and disadvantages. The main strength of the QWI data is that they capture the universe of workers covered by the UI system, while the ACS samples are small for the specific occupations analyzed here. Indeed, the QWI estimates are generally more precise. The inverse wage setting elasticities are 2.2 for real estate agents, 4.3 for architects, and 3.5 for construction workers.

While individual estimates differ somewhat, the general pattern of results is quite consistent across the two data sets. Real estate agents have the most elastic wage setting schedule. This indicates that the employment of realtors reacts less to wage fluctuations. The relatively more elastic wage setting schedule for architects and construction workers, on the other hand, indicates that sizeable employment fluctuations and small wage changes happen in response to demand shocks for these occupations. 
There is a sizeable literature on downward nominal wage rigidity and many economists believe that this is a source of employment fluctuations over the business cycle. Nevertheless, there is not much evidence linking rigid wages directly to employment outcomes as I have done here. I do indeed find that the wages of real estate agents react more and employment less to labor demand shocks than they do for architects and construction workers, who tend to have more rigid wage setting institutions. Comparing narrow occuapations which work in a highly cyclical industry is attractive because we have a good sense how pay setting institutions differ across these occupations.

But focusing on narrow occupations also has shortcomings. Neither the ACS nor the QWI are ideal data sources for this exercise. Even in the ACS, cell sizes for real estate agents or architects at the state-year level are small. The QWI is not ideally suited to capture occupations like real estate agents who often work as independent contractors, it only identifies workers by industry not occupation, and it only measures total quarterly earnings rather than hourly wages. These complications are likely all contributing to the realtively noisy results. It is therefore comforting that a fairly consistent pattern of results still emerges from both data sets.

Both data sets are effectively repeated cross-sections and hence are subject to the problem that the composition of the workforce is changing over the cycle. Typically, lower paid workers are more likely to leave an occupation in a downturn. This would make wages look less cyclical than they are and will bias the inverse wage setting elasticities upwards. It is difficult to gauge how much this problem differs across the three occupations. We might expect this to affect real estate agents the most since this is the group with the largest employment response to the cyclical shocks. As a result, differences between occupations would be larger than those apparent in Table 3. Comprehensive panel data on these occupations would be necessary to say more on this problem. ${ }^{8}$

How big are the differences in employment responses of real estate agents and the other occupations? The estimates for the wage setting elasticity are not particularly precise and the

\footnotetext{
${ }^{8}$ Sample sizes in Current Population Survey matched across years are too small to make any headway on this.
} 
specific results differ somewhat between the ACS and QWI estimates. It is still useful to take the estimates at face value and consider their implications. Real estate agents exhibit the smallest wage setting elasticities among the three occupations in both data sets but the wage setting elasticities for them of 2.2 to 3.5 are still sizeable. Consider an occupation where wages are completely fixed, so that a labor demand shock translates one for one into a change in employment. Compared to this benchmark, employment for real estate agents would contract by $\theta /(\theta+\eta)$ in a simple static demand and supply framework, where $\theta$ is the wage setting elasticity as before, and $\eta$ is minus the elasticity of labor demand. Setting $\eta=0.5$ (as in Card, 1990) ${ }^{9}$ and $\theta=2.2$ would imply employment declining by 82 percent of the benchmark case; or 88 percent for $\theta=3.5$. Since wage setting of architects and construction workers is not completely elastic either this does not seem like a huge difference compared to these more fixed wage occupations. Hence, if flexibility of wage setting is one of the sources of employment fluctuations over the business cycle, then moving all occupations to the same level of flexibility as exhibited by real estate agents would still leave a large part of these employment fluctuations in place unless labor demand is much more elastic.

\footnotetext{
${ }^{9}$ Hamermesh (1993) puts the consensus estimate of the own elasticity of labor demand even lower at 0.3 .
} 


\section{References}

AIA (2011), AIA Compensation Report 2011. Washington, DC.

Altonji, Joseph G. and Paul J. Devereux (2000), “The Extent and Consequences of Downward Nominal Wage Rigidity,” in: Polachek, Solomon W. (ed.) Worker well-being. Research in Labor Economics, 19, 383-431.

Baker, George, Michael Gibbs, and Bengt Holmstrom (1994), “The Wage Policy of a Firm,” Quarterly Journal of Economics, 109, no. 4, 921-955.

Beaudry, Paul, and John DiNardo (1991), "The Effect of Implicit Contracts on the Movement of Wages over the Business Cycle: Evidence from Micro Data.” Journal of Political Economy, 99, no. 4, 665-688.

Bewley, Truman F. (2002), Why Wages Don't Fall during a Recession, Cambridge, MA: Harvard University Press.

Card, David (1990), “Unexpected Inflation, Real Wages, and Employment Determination in Union Contracts,” American Economic Review, 80, no. 4, 669-688.

Card, David and Dean Hyslop (1997), "Does Inflation 'Grease the Wheels of the Labor Market’?”, in Christina D. Romer and David H. Romer (eds.), Reducing Inflation: Motivation and Strategy. Chicago: University of Chicago Press.

Card, David, Francis Kramarz, and Thomas Lemieux (1999), “Changes in the Relative Structure of Wages and Employment: A Comparison of the United States, Canada, and France,” Canadian Journal of Economics, 32, no. 4, 843-877.

Case, Karl E. and Robert J. Shiller (1989), “The Efficiency of the Market for Single-Family Homes,” American Economic Review, 79, no. 1, 125-137.

Dickens, William T., Lorenz Goette, Erica L. Groshen, Steinar Holden, Julian Messina, Mark E. Schweitzer, Jarkko Turunen, and Melanie E. Ward. (2007), "How Wages Change: Micro Evidence from the International Wage Flexibility Project," Journal of Economic Perspectives, 21, no. 2, 195-214.

Elsby, Michael W., Donggyun Shin, and Gary Solon (2016), "Wage Adjustment in the Great Recession and Other Downturns: Evidence from the United States and Great Britain,” Journal of Labor Economics, 34, no. S1, S249-S291

Fehr, Ernst and Lorenz Goette (2005), "Robustness and Real Consequences of Nominal Wage Rigidity,” Journal of Monetary Economics, 52, no. 4, 779-804.

Glaeser, Edward, Joseph Gyourko, and Raven Saks (2005), "Why Have Housing Prices Gone Up?” American Economic Review Papers and Proceedings, 95, 329-333. 
Glaeser, Edward, Joseph Gyourko, and Albert Saiz (2008), "Housing Supply and Housing Bubbles,” Journal of Urban Economics, 64, no. 2, 198-217.

Gyourko, Joseph, and Albert Saiz (2006), "Construction Costs and the Supply of Housing Structure,” Journal of Regional Science, 46, no. 4, 661-680.

Hamermesh, Daniel S. (1993) Labor Demand. Princeton: Princeton University Press.

Holzer, Harry J. and Edward B. Montgomery (1993), “Asymmetries and Rigidities in Wage Adjustments by Firms,” Review of Economics and Statistics, 75, no. 3, 397-408.

Hsieh, Chang-Tai and Enrico Moretti (2003), “Can Free Entry Be Inefficient? Fixed Commissions and Social Waste in the Real Estate Industry,” Journal of Political Economy, 111, no. 5, 1076-1122.

Kahn, Shulamit (1997), "Evidence of Nominal Wage Stickiness from Microdata.” American Economic Review, 87, no. 5, 993-1008.

Kaur, Supreet (2014), “Nominal Wage Rigidity in Village Labor Markets,” NBER Working Paper No. 20770, December.

Lemieux, Thomas, W. Bentley MacLeod, and Daniel Parent (2012), "Contract Form, Wage Flexibility, and Employment,” American Economic Review Papers and Proceedings, 102, 526-531.

NAR (2014), 2013 Members Profile. NAR, Washington DC.

NAR RealtorMag (2014a), Common Commission Options. [Online] http://realtormag.realtor.org/tool-kit/retention/article/common-commission-options. [Accessed Aug 27, 2015].

NAR RealtorMag (2014b), Determining Employee Status. [Online] http://realtormag.realtor.org/tool-kit/employment/article/determining-employee-status. [Accessed Aug 27, 2015].

PAS (2014), 2014 Merit Shop Wage and Benefit Survey. Saline, MA.

Pissarides, Christopher A. (2009), "The Unemployment Volatility Puzzle: Is Wage Stickiness the Answer?” Econometrica, 77, no. 5, 1339-1369.

Shelef, Orie and Amy Nguyen-Chyung (2015), "Competing for Labor through Contracts: Selection, Matching, Firm Organization and Investments,” mimeographed, Stanford University. 
Figure 1: Housing Market Fluctuations in Three States

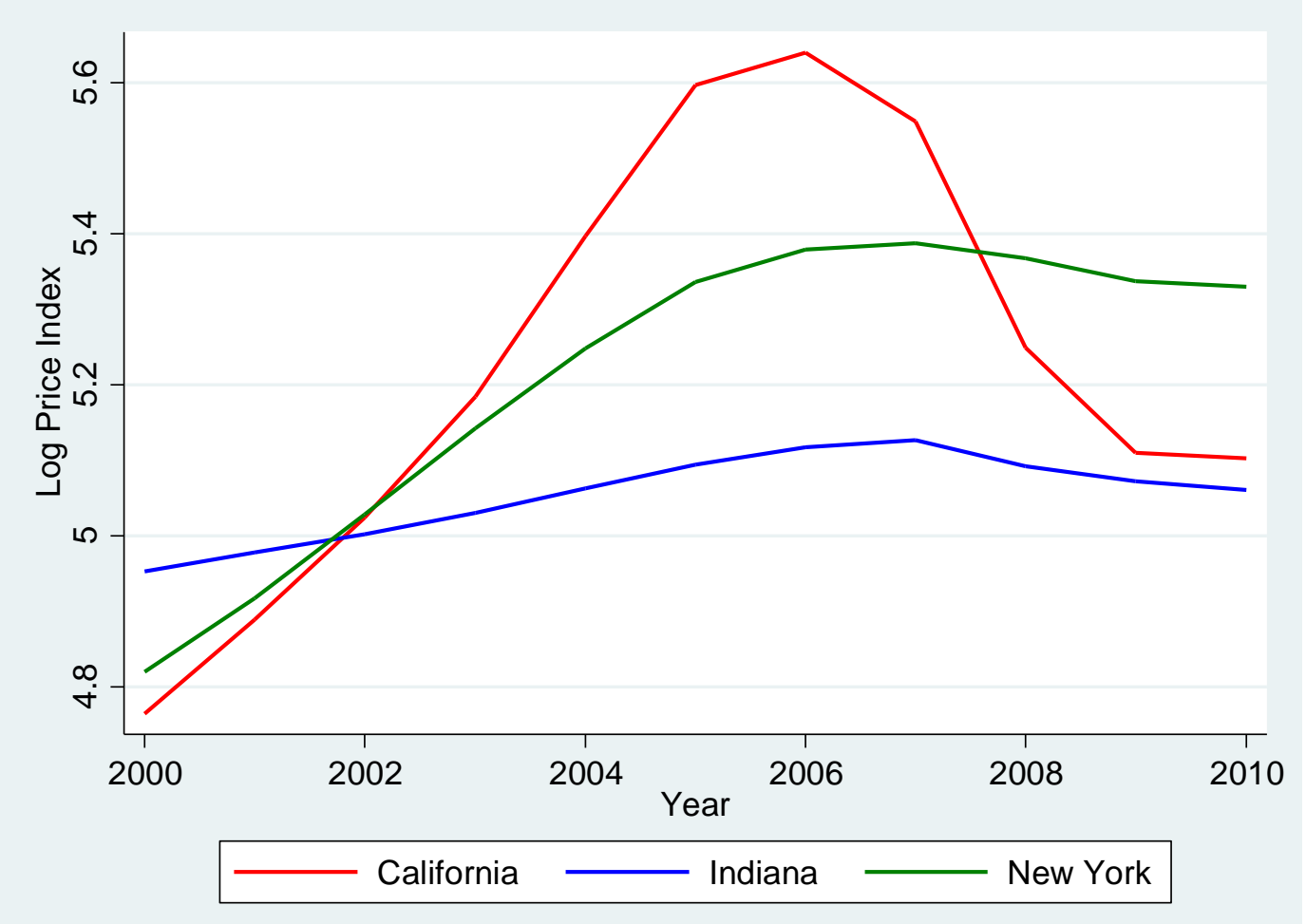


Figure 2: Contract for a Real Estate Agent

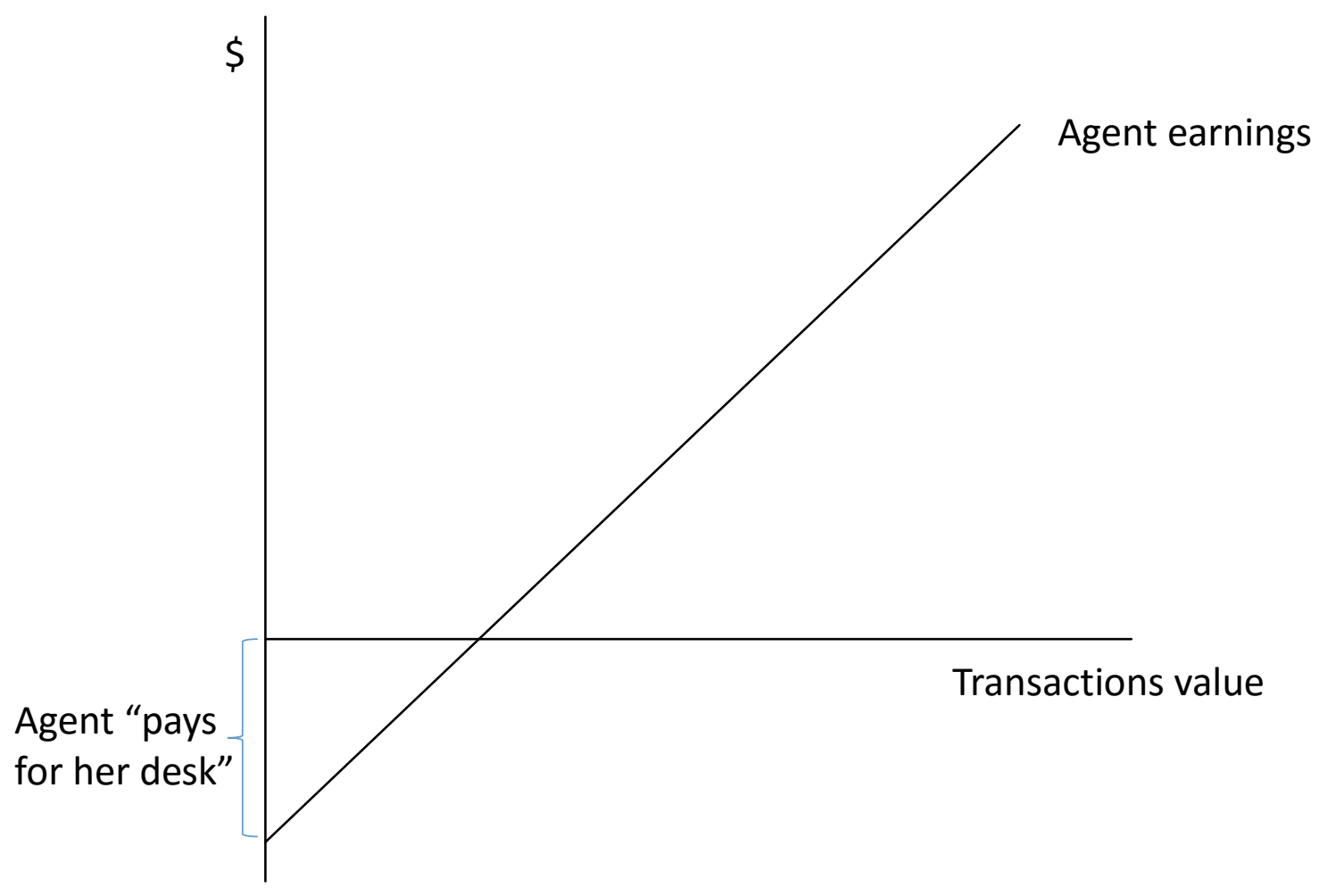


Figure 3: The Labor Market for Housing Related Occupations

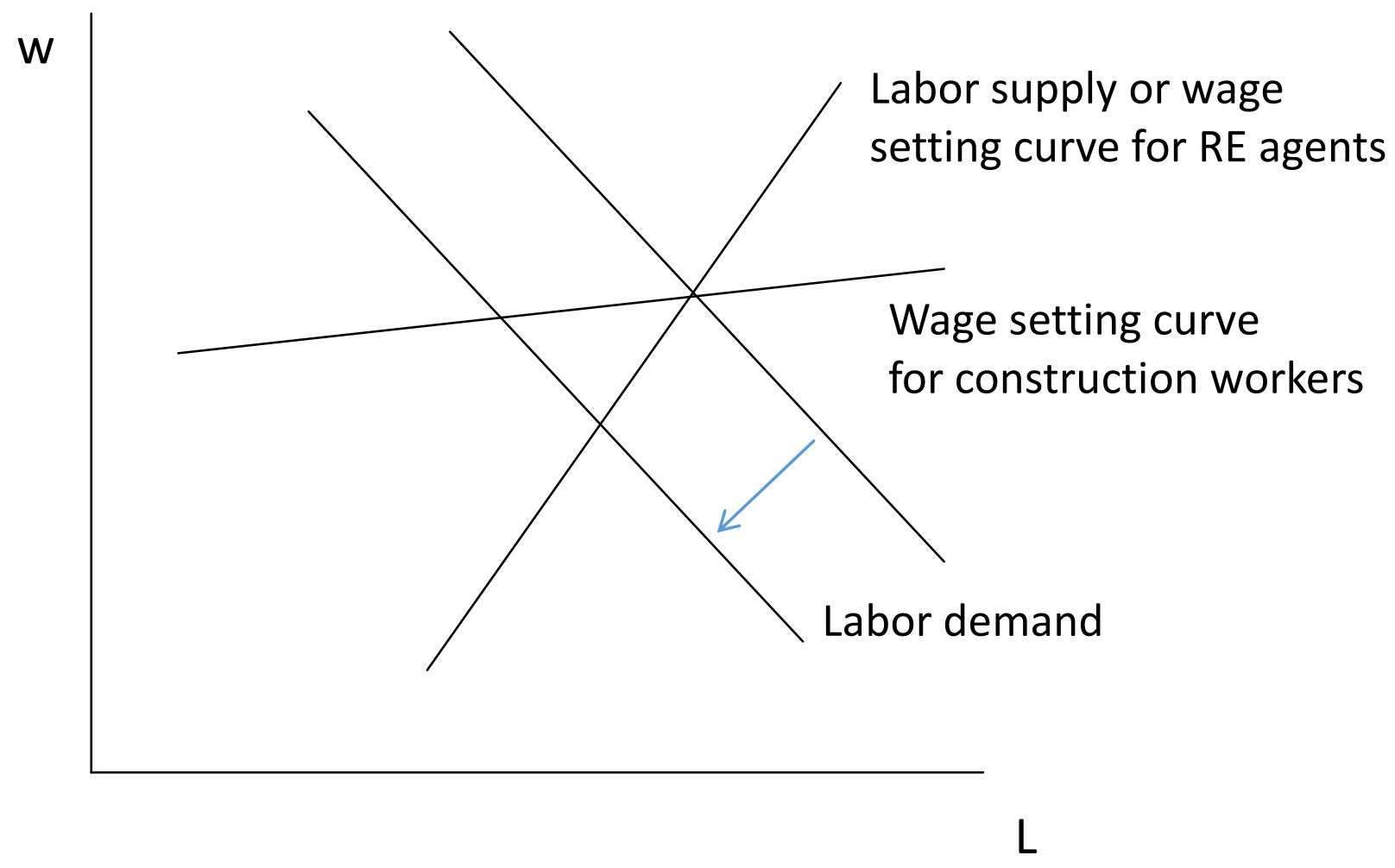


Table 1: Prevalence of Flexible Pay in Housing Related Occupations

\begin{tabular}{|c|c|c|c|c|c|}
\hline Occupation & $\begin{array}{l}\text { Source } \\
\text { (1) }\end{array}$ & $\begin{array}{l}\text { Year } \\
(2)\end{array}$ & $\begin{array}{c}\text { Occupation } \\
\text { definition } \\
\text { (3) }\end{array}$ & $\begin{array}{l}\text { Flexible pay } \\
\text { definition } \\
\text { (4) }\end{array}$ & $\begin{array}{c}\text { Value } \\
\text { (Percent) } \\
\text { (5) }\end{array}$ \\
\hline \multicolumn{6}{|c|}{ Share of workers receiving flexible pay } \\
\hline Real Estate Agents & $\begin{array}{c}\text { CPS } \\
\text { MORG }\end{array}$ & $\begin{array}{l}1991- \\
2010\end{array}$ & Census Code & $\begin{array}{l}\text { Overtime, tips, } \\
\text { commissions }\end{array}$ & 51 \\
\hline Real Estate Agents & NAR & 2013 & $\begin{array}{l}\text { Sales Agents \& } \\
\text { Brokers }\end{array}$ & $\begin{array}{l}\text { Workers with } \\
\text { flexible pay } \\
\text { component }\end{array}$ & 95 \\
\hline Architects & $\begin{array}{c}\text { CPS } \\
\text { MORG }\end{array}$ & $\begin{array}{l}1991- \\
2010\end{array}$ & Census Code & $\begin{array}{l}\text { Overtime, tips, } \\
\text { commissions }\end{array}$ & 12 \\
\hline $\begin{array}{l}\text { Construction } \\
\text { Workers }\end{array}$ & $\begin{array}{c}\text { CPS } \\
\text { MORG }\end{array}$ & $\begin{array}{l}1991- \\
2010\end{array}$ & Census Code & $\begin{array}{l}\text { Overtime, tips, } \\
\text { commissions }\end{array}$ & 13 \\
\hline \multicolumn{6}{|c|}{ Share of flexible pay in income for workers receiving it } \\
\hline Architects & AIA & 2011 & $\begin{array}{c}\text { Architect excl. } \\
\text { managerial } \\
\text { roles }\end{array}$ & $\begin{array}{l}\text { Overtime, bonus, } \\
\text { and incentive } \\
\text { compensation }\end{array}$ & 5 \\
\hline Construction worker & $\begin{array}{l}\text { Dietrich } \\
\text { Surveys }\end{array}$ & 2014 & $\begin{array}{l}\text { Construction } \\
\text { coordinator } \\
\text { and field } \\
\text { engineer }\end{array}$ & $\begin{array}{l}\text { Diff between base } \\
\text { pay and all } \\
\text { earnings (excl. } \\
\text { overtime) }\end{array}$ & 5 \\
\hline Construction worker & PAS & 2014 & $\begin{array}{l}\text { Journeymen } \\
\text { All trades }\end{array}$ & $\begin{array}{l}\text { Fringe costs to } \\
\text { firms (excl. } \\
\text { overtime) }\end{array}$ & 19 \\
\hline
\end{tabular}

Sources: NAR: NAR (2014), Exhibit 3-1: sales agents with commissions or profit sharing; AIA: AIA (2011), Exhibit 1-5: architects and designers in all firm; Dietrich Surveys: Personal email correspondence with Wayne Dietrich on July 31, 2014; PAS: PAS (2014), p. 7, average fringe.

Notes: CPS percentages in the top panel refer to employed workers only; percentage from the NAR refers to sales agents. 
Table 2: Wage and Employment Cyclicality of Real Estate Agents

\begin{tabular}{|c|c|c|c|c|c|c|c|c|c|c|c|c|}
\hline & \multicolumn{12}{|c|}{ Dependent variable } \\
\hline & \multicolumn{3}{|c|}{ ln hourly wage } & \multicolumn{3}{|c|}{ ln employed individuals } & \multicolumn{3}{|c|}{ ln average weeks } & \multicolumn{3}{|c|}{ ln average weekly hours } \\
\hline & $(1)$ & $(2)$ & (3) & $(4)$ & (5) & (6) & $(7)$ & $(8)$ & $(9)$ & $(10)$ & $(11)$ & $(12)$ \\
\hline $\ln$ HPI $(P)$ & $\begin{array}{c}0.144 \\
(0.066)\end{array}$ & & & $\begin{array}{c}0.611 \\
(0.129)\end{array}$ & & & $\begin{array}{l}-0.002 \\
(0.025)\end{array}$ & & & $\begin{array}{c}-0.032 \\
(0.023)\end{array}$ & & \\
\hline ln HPI x sales & & $\begin{array}{c}0.153 \\
(0.060)\end{array}$ & $\begin{array}{c}0.138 \\
(0.076)\end{array}$ & & $\begin{array}{c}0.537 \\
(0.101)\end{array}$ & $\begin{array}{c}0.585 \\
(0.107)\end{array}$ & & $\begin{array}{c}0.006 \\
(0.022)\end{array}$ & $\begin{array}{c}0.019 \\
(0.027)\end{array}$ & & $\begin{array}{c}-0.014 \\
(0.017)\end{array}$ & $\begin{array}{l}-0.005 \\
(0.023)\end{array}$ \\
\hline $\begin{array}{l}\text { ln alternative } \\
\text { wage }\end{array}$ & & & $\begin{array}{c}0.341 \\
(0.599)\end{array}$ & & & $\begin{array}{c}-1.052 \\
(0.956)\end{array}$ & & & $\begin{array}{c}-0.292 \\
(0.240)\end{array}$ & & & $\begin{array}{c}-0.197 \\
(0.274)\end{array}$ \\
\hline
\end{tabular}

Notes: The regressions are based on 559 state-year observations spanning the period from 2000 to 2010. All models include year and state fixed effects and are estimated using weighted least squares, with the number of individuals represented by an aggregate state observation as weight. The dependent variable is constructed by aggregating individual data from the ACS at the state-year level. Standard errors in parentheses are clustered at the state level. 
Table 3: Wage and Employment Cyclicality of Different Housing Related Occupations

\begin{tabular}{|c|c|c|c|c|c|c|}
\hline & \multicolumn{3}{|c|}{ ACS by occupation } & \multicolumn{3}{|c|}{ QWI by industry } \\
\hline & $\begin{array}{l}\text { realtor } \\
\text { (1) }\end{array}$ & $\begin{array}{l}\text { architect } \\
\text { (2) }\end{array}$ & $\begin{array}{c}\text { construction } \\
\text { (3) }\end{array}$ & $\begin{array}{c}\text { realtor } \\
(4)\end{array}$ & $\begin{array}{l}\text { architect } \\
\text { (5) }\end{array}$ & $\begin{array}{c}\text { construction } \\
\text { (6) }\end{array}$ \\
\hline employment effect & $\begin{array}{c}0.537 \\
(0.101)\end{array}$ & $\begin{array}{c}0.357 \\
(0.109)\end{array}$ & $\begin{array}{c}0.333 \\
(0.063)\end{array}$ & $\begin{array}{c}0.386 \\
(0.082)\end{array}$ & $\begin{array}{c}0.293 \\
(0.065)\end{array}$ & $\begin{array}{c}0.497 \\
(0.094)\end{array}$ \\
\hline weekly hours effect & $\begin{array}{l}-0.014 \\
(0.017)\end{array}$ & $\begin{array}{l}-0.073 \\
(0.025)\end{array}$ & $\begin{array}{c}0.030 \\
(0.009)\end{array}$ & & & \\
\hline wage effect & $\begin{array}{c}0.153 \\
(0.060)\end{array}$ & $\begin{array}{c}0.095 \\
(0.057)\end{array}$ & $\begin{array}{c}0.012 \\
(0.016)\end{array}$ & $\begin{array}{c}0.173 \\
(0.039)\end{array}$ & $\begin{array}{c}0.069 \\
(0.022)\end{array}$ & $\begin{array}{c}0.140 \\
(0.051)\end{array}$ \\
\hline $\begin{array}{l}\text { inverse wage setting } \\
\text { elasticity }\end{array}$ & $\begin{array}{c}3.50 \\
(1.35)\end{array}$ & $\begin{array}{l}3.75 \\
(2.19)\end{array}$ & $\begin{array}{c}27.23 \\
(33.70)\end{array}$ & $\begin{array}{l}2.23 \\
(0.73)\end{array}$ & $\begin{array}{c}4.27 \\
(0.90)\end{array}$ & $\begin{array}{c}3.55 \\
(1.34)\end{array}$ \\
\hline
\end{tabular}

Note: Sample period is 2000-2010 for the ACS (559 observations, architects 539 due to empty cells) \& 1991-2010 for the QWI (667 observations). ACS groups are based on occupation, QWI groups based on industry. Cycle variable is total value of house transactions (price x volume). Average wage is the hourly wage for ACS, the monthly wage for QWI. Regressions are weighted with the number of individuals represented by an aggregate state observation as weight. Standard errors in parentheses are clustered at the state level. 


\section{Appendix}

Availability of QWI data by state

\begin{tabular}{|c|c|c|c|c|c|}
\hline State & Start year & $\begin{array}{c}\text { Start } \\
\text { quarter }\end{array}$ & State & Start year & $\begin{array}{c}\text { Start } \\
\text { quarter }\end{array}$ \\
\hline$\overline{A K}$ & 2000 & 1 & MT & 1993 & 1 \\
\hline $\mathrm{AL}$ & 2001 & 1 & $\mathrm{NC}$ & 1992 & 4 \\
\hline AR & 2002 & 3 & ND & 1998 & 1 \\
\hline AZ & 2004 & 1 & $\mathrm{NE}$ & 1999 & 1 \\
\hline CA & 1991 & 3 & $\mathrm{NH}$ & 2003 & 1 \\
\hline $\mathrm{CO}$ & 1993 & 2 & $\mathrm{NJ}$ & 1996 & 1 \\
\hline CT & 1996 & 1 & NM & 1995 & 3 \\
\hline DC & 2005 & 2 & $\mathrm{NV}$ & 1998 & 1 \\
\hline $\mathrm{DE}$ & 1998 & 3 & NY & 2000 & 1 \\
\hline FL & 1997 & 4 & $\mathrm{OH}$ & 2000 & 1 \\
\hline GA & 1998 & 1 & $\mathrm{OK}$ & 2000 & 1 \\
\hline HI & 1995 & 4 & OR & 1991 & 1 \\
\hline IA & 1998 & 4 & PA & 1997 & 1 \\
\hline ID & 1991 & 1 & RI & 1995 & 1 \\
\hline IL & 1993 & 2 & $\mathrm{SC}$ & 1998 & 1 \\
\hline IN & 1998 & 1 & SD & 1998 & 1 \\
\hline $\mathrm{KS}$ & 1993 & 1 & $\mathrm{TN}$ & 1998 & 1 \\
\hline $\mathrm{KY}$ & 2001 & 1 & TX & 1995 & 1 \\
\hline LA & 1995 & 1 & UT & 1999 & 3 \\
\hline MA & NA & & VA & 1998 & 3 \\
\hline MD & 1990 & 1 & VT & 2000 & 1 \\
\hline $\mathrm{ME}$ & 1996 & 2 & WA & 1990 & 1 \\
\hline MI & 2000 & 3 & WI & 1990 & 1 \\
\hline $\mathrm{MN}$ & 1994 & 3 & WV & 1997 & 1 \\
\hline MO & 1995 & 1 & WY & 2001 & 1 \\
\hline MS & 2003 & 3 & & & \\
\hline
\end{tabular}

